\title{
READERS
Insight
}

Journal of Economic Info (JEI)

ISSN:2313-3376

www.readersinsight.net/jei

\section{The Impact of Different Firm Sizes on Capital Structure Determinants among Listed Consumer Product Firms in Malaysia}

\author{
Ahmad Amirul Arsyad bin Noraidi', Dr. Suresh Ramakrishnan² \\ ${ }^{1,2}$ Faculty of Management, Universiti Teknologi Malaysia, 81310, Skudai, Johor, Malaysia. \\ *Corresponding author: aaarsyadn@gmail.com
}

\begin{abstract}
This research is conducted to determine the impact of different firm sizes on the relationship between capital structure determinants and leverage among listed consumer product firms in Malaysia from year 2006 to 2015. All data was taken from annual report of the companies by using DataStream. In 2015, 130 firms were listed in Bursa Malaysia under the consumer product sector. However, only 108 firms were observed as several firms had insufficient data. This study uses the dependent variable of debt ratios i.e. short-term debt, long-term debt and total debt. The independent variables used are firm size, profitability, tangibility, liquidity, growth, non-tax debt shield and business risk. Those results were obtained by applying Pooled OLS and Fixed Effect Analysis. The main finding of this study is that different firm sizes will affect the relationship between capital structure determinants and leverage. The Fixed Effect analysis revealed that all determinants were significant across all types firm sizes. Furthermore, non-tax debt shield had the largest impact to all types of leverage across different firm sizes.
\end{abstract}

Keywords: Capital Structure, Leverage, Consumer Product, Firm Size, Determinants
ARTICLE INFORMATION

Received: 25 January 2018 Revised: $\quad 12$ March 2018 Accepted: 25 March 2018 DOI: $10.31580 /$ jei.v5i2.104

\section{INTRODUCTION}

Capital structure is where a firm uses a mixture of different sources of funds to finance the firm. It can be in the form of debt or equity being bonds and notes for debt, while stocks and retained profit are equities. A firm can maximize their value and minimize the cost of financing if they achieve optimal capital structure. Although, every firm will have a different optimal capital structure as a firm's characteristics and several other factors affects a firm's level of optimal capital structure. Most of the research examined the importance of capital structure determinants across countries. Nonetheless, sectors within a country have varying financing patterns due to each sector being unique on its own. Other than that, more than a few researchers have examined capital structures across sectors (Tornyeva, 2013); (Wellalage, N. H., 2013); (Cortez, M. A., \& Susanto, 2012); (Khrawish and Khraiwesh, 2010). Besides that, the capital structure among firms in Malaysia also have been examined (Saarani and Shahadan, 2013); (Haron and Ibrahim, 2012); (Pandey and Chotigeat, 2004). On the other hand, (Haron, 2014), (Md-Yusuf et al., 2013), (Affandi et al., 2012), (Wahab et al., 2012) provided understandings of capital structure decisions by focusing on specific sectors within Malaysia. In addition, there is little research done on the impact of different firm sizes on capital structure determinants among listed consumer product firms in Malaysia. Decisions on a firms' capital structure may differ based on the firms sizes due to different characteristics that larger firms may have compared to smaller firms. Therefore, this study aims to investigate whether the capital structure decision of consumer products firms listed on Bursa Malaysia can be explained by firm-specific determining factors namely, firm size, risk, liquidity, growth, tangibility, profitability and non-tax debt shield. Furthermore, to investigate whether those decisions will differ across different firm sizes.

\section{Objectives of the Study}

1) To examine the significant determinants of capital structure within the consumer product sector in Malaysia.

2) To examine the impact of different firm sizes on capital structure determinants within consumer product sector Malaysia.

3) To determine the behavior of the sector explained by capital structure theories.

\section{LITERATURE REVIEW}

Based on the traditional approach to capital structure, an optimal capital structure exists that maximizes a firm's value through an increase in leverage. (Modigliani and Miller, 1958) theorized that a firm's value is unaffected by the capital structure, given a flawless capital market assuming there are no taxes, no agency costs, and bankruptcy costs, and also where information failure does not occur. The trade-off theory is modified from the MM theory which includes the effect of taxes on the capital structure. The pecking order theory pioneered by (Myers and Majluf, 1984) highlighted the effects of asymmetric information among managers and investors.

As larger firms are more diversified and their cash flows are more stable, leverage will increase with the size. Larger firm's bankruptcy cost would also be lower than smaller firms due to the size of the firm. (Wellalage, N. H., 2013), found that firm size and leverage is 
significantly positively related. However, (Pacheco and Tavares, 2017), and (Proença et al., 2014) both found the opposite result for Portuguese SMEs, where size resulted in a negative relationship with short term debt and long term debt is positively related to size of firm. However, the relationship between size of a firm and total debt is found to be positive in several Malaysian studies (Md-Yusuf et al., 2013); (Affandi et al., 2012).

Studies by (Alzomaia, 2014), (Wellalage, N. H., 2013), (AlNajjar, 2011), and (Feidakis, A., \& Rovolis, 2007) showed that there is a negative relationship between risk and leverage. Nevertheless, (Ramakrishnan, 2012), and (Pandey and Chotigeat, 2004) showed that there is a positive relationship between risk and short-term debt while risk is negatively related to long-term debt. (Al-Najjar, 2011) found that when firms have high liquidity, they will increase their leverage. Meanwhile, (Proença et al., 2014) and (Abu Mouamer, 2011) emphasized a mix of liquidity and leverage, where liquidity is negatively related to short-term debt while positively related to longterm debt. (Wahab, S. N., \& Ramli, 2014), (Haron, 2014), and (Haron and Ibrahim, 2012) found that liquidity has a negative relationship to long-term debt and total debt among Malaysian firms. Numerous studies have showed that growth and leverage is positively related (Alzomaia, 2014); (Wellalage, N. H., 2013); (Shah and Jam-e-Kausar, 2012). Although, (Haron, 2014), (Saarani and Shahadan, 2013), and (Haron and Ibrahim, 2012) found that there is a negative relationship between growth and short-term and long-term debt.

Several researchers emphasized that tangibility and leverage is negatively related supporting the pecking order theory (Jahanzeb et al., 2015); (Alzomaia, 2014); (Wellalage, N. H., 2013); (Ahmed Sheikh and Wang, 2011); (Sbeiti, 2010). Other than that, it was concluded by (Proença et al., 2014) that there is a positive relationship between tangibility and long-term debt, while it is negatively related to short-term debt. Numerous studies have confirmed that profitability has a negative relationship with leverage, supporting the pecking order theory (Pacheco and Tavares, 2017); (Alzomaia, 2014); (Gómez et al., 2014); (Proença et al., 2014).

On the contrary, (Wahab, S. N., \& Ramli, 2014) and (Affandi et al., 2012) confirmed that in Malaysia, firms tend to reduce their debt capacity when they have high profit that follows the pecking order theory. Empirical studies by (Gómez et al., 2014), (Cortez, M. A., \& Susanto, 2012) and (Viviani, 2008) have confirmed that non-tax debt shield is negatively related with leverage. (Ramakrishnan, 2012) found that there is a positive relationship between non-tax debt shield and short-term debt while a negative relationship with long-term debt.

\section{METHODOLOGY}

906 firms were listed on Bursa Malaysia as at 2015. The population used in the study comprised of firms within the consumer products sector in Malaysia across 10 years, i.e. from 2006 to 2015. 130 consumer product firms were listed on Bursa Malaysia. Although, out of the 130 firms, several firms were not included due to insufficient data. Thus, the financial data of the 108 firms were used to understand the relationship between leverage and capital structure determinants. Data was collected from annual reports of consumer product firms using DataStream.

\section{Variables}

Total debt, short-term debt and long-term debt which are measurements for leverage ratios were used as dependent variables in order to obtain a better understanding of the capital structure in Malaysia. The book leverage ratios were used instead of the market value leverage in this study. A summary of the dependent variable is explained in table 3.1 .

Table 3.1: Dependent Variables

\begin{tabular}{ll}
\hline Variables & Formulation \\
\hline Total debt & Total debt divided by the book value of total assets
\end{tabular}

Short term debt Short term debt divided by the book value of total assets

Long term debt Long term debt divided by the book value of total assets

This study focused on firm-level variables. Based on the variables commonly used in most of the studies conducted on Malaysia, seven firm-level determinants were chosen, namely tangibility, profitability, liquidity, size of the firm, growth, opportunities, risk and non-tax debt shield to be used as independent variables. A summary of the independent variable is illustrated in table 3.2.

Table 3.2: Independent Variable

\begin{tabular}{|c|c|}
\hline Variables & Formulation \\
\hline Tangibility & Fixed assets / Total assets \\
\hline Profitability & $\begin{array}{l}\text { Earnings before interest and taxes / Total } \\
\text { assets }\end{array}$ \\
\hline Liquidity & Current assets / Current liabilities \\
\hline Firm size & Natural logarithm of sales \\
\hline $\begin{array}{l}\text { Growth } \\
\text { opportunities }\end{array}$ & $\begin{array}{l}\text { Market to book ratio (Market price per share / } \\
\text { Book value per share) }\end{array}$ \\
\hline Risk & $\begin{array}{l}\text { ((Earnings before interest and taxes / Total } \\
\text { assets) - Mean (Earnings before interest and } \\
\text { taxes / Total assets }))^{\wedge} 2\end{array}$ \\
\hline Non-tax debt shield & Depreciation / Total assets \\
\hline
\end{tabular}

\section{Hypotheses}

The hypotheses of the study are stated as below as discussed in chapter 2:

H1: There is negative relationship between firm size and shortterm debt.

H2: There is positive relationship between firm size and longterm debt.

H3: There is positive relationship between firm size and total debt.

H4: There is negative relationship between risk and short-term debt.

H5: There is positive relationship between risk and long-term debt.

H6: There is negative relationship between risk and total debt.

H7: There is negative relationship between liquidity and shortterm debt.

H8: There is negative relationship between liquidity and longterm debt.

H9: There is negative relationship between liquidity and total debt.

H10: There is negative relationship between growth and shortterm debt.

H11: There is negative relationship between growth and longterm debt.

H12: There is positive relationship between growth and total debt.

H13: There is negative relationship between tangibility and shortterm debt.

H14: There is positive relationship between tangibility and longterm debt. debt.

H15: There is positive relationship between tangibility and total

H16: There is negative relationship between profitability and short-term debt.

H17: There is negative relationship between profitability and long-term debt.

H18: There is negative relationship between profitability and total debt.

H19: There is positive relationship between non-tax debt shield and short term debt.

H20: There is negative relationship between non-tax shield and long-term debt. 
H21: There is negative relationship between non-tax shield and total debt.

H22: There is different relationship between capital structure determinants and leverage among different firm sizes.

\section{FINDINGS}

\section{Descriptive Summary and Correlation Matrix Analysis}

Table 4.1 illustrates the descriptive statistics of firm-level determinants consisted of mean, minimum and maximum, the standard deviation, and also the observations for dependent and independent variables. The result revealed that $19 \%$ of firms funding is financed by total debt. This percentage is mainly contributed by short-term debt which is about $65 \%-70 \%$ of total debt. Other than that, the standard deviation reveals that total debt ratio is the most volatile followed by short-term debt ratio. Firm size is found to have the strongest average position among the firms in the consumer product sector followed by liquidity and growth. Moreover, it can be seen that liquidity, growth and business risk have high volatility across the firms in consumer product sector.

\begin{tabular}{llllll}
\multicolumn{6}{l}{ Table 4.1: Descriptive Statistics of Firm-level Determinants } \\
\hline Variable & Mean & Std Dev. & Min & Max & Obs \\
\hline STD & 0.135 & 0.145 & 0.000 & 2.375 & 1080 \\
LTD & 0.057 & 0.084 & 0.000 & 0.667 & 1080 \\
TD & 0.192 & 0.178 & 0.000 & 2.375 & 1080 \\
FSIZE & 5.272 & 0.809 & 0.000 & 7.200 & 1080 \\
PROF & 0.070 & 0.416 & -11.735 & 5.547 & 1080 \\
LQTY & 2.792 & 3.281 & 0.000 & 45.860 & 1080 \\
TANG & 0.358 & 0.188 & 0.000 & 0.938 & 1080 \\
GRTH & 1.594 & 3.708 & -16.000 & 38.399 & 1080 \\
NDTS & 0.032 & 0.016 & 0.000 & 0.137 & 1080 \\
BRISK & 0.145 & 3.482 & 0.000 & 111.772 & 1080
\end{tabular}

This table shows the mean, standard deviation, minimum, maximum and number of observations for leverage and firm-level determinants across the consumer product sector. The overall sample consists of 1080 firm-year observations from 2006 to 2015. The dependent variables are book leverage ratios (short term debt to total asset (STD), long-term debt to total asset (LTD) and total debt to total asset (TD)). The independent variables are firm size (FSIZE), profitability (EBIT), liquidity (LQTY), tangibility (TANG), growth (GRTH), non-tax debt shield (NDTS) and business risk (BRISK).

Table 4.2: Correlation Matrix of Firm-level Determinants

\begin{tabular}{|c|c|c|c|c|c|c|c|}
\hline & FSIZE & PROF & LQTY & TANG & GRTH & NDTS & BRISK \\
\hline FSIZE & 1.000 & 0.275 & $-0.060^{\star *}$ & 0.026 & $0.303^{* *}$ & $0.147^{\star *}$ & $-0.201^{* *}$ \\
\hline PROF & & 1.000 & $0.094^{\star *}$ & -0.018 & $0.232^{\star *}$ & 0.048 & $-0.761^{* *}$ \\
\hline LQTY & & & 1.000 & $-0.213^{\star *}$ & $-0.063^{\star \star}$ & $-0.145^{\star *}$ & 0.011 \\
\hline TANG & & & & 1.000 & -0.033 & $0.544^{\star \star}$ & $-0.063^{\star *}$ \\
\hline GRTH & & & & & 1.000 & $0.143^{* *}$ & -0.023 \\
\hline NDTS & & & & & & 1.000 & -0.008 \\
\hline BRISK & 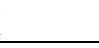 & & & & & & 1.000 \\
\hline
\end{tabular}

This table illustrates the correlation matrix between leverage and firm-level determinants across consumer product sector. The sample consist of 1080 firm-year observations from 2006 to 2015. The independent variables are firm size (FSIZE), profitability (EBIT), liquidity (LQTY), tangibility (TANG), growth (GRTH), non-tax debt shield (NDTS) and business risk (BRISK).

Table 4.2 shows a correlation matrix based on 108 firms across consumer product sector in Malaysia. From this table, we can see that firm size has significant negative relationship with liquidity and business risk while being positively related to growth and non-tax debt shield at 5\% level. Conversely, liquidity is significant and negatively correlated to tangibility, growth and non-tax debt shield. Besides that, profitability is positively related and significant to liquidity and growth while being negatively related to business risk at $5 \%$ significance level.

\section{Pooled OLS Analysis Based on Overall Samples}

As illustrated in Table 4.3, firm size was positively related to short-term debt at $1 \%$ significance level. This is contrary to the proposed hypotheses H1. Thus, this hypothesis was rejected. Firm size was found to be positively related with long-term debt and total debt at $10 \%$ and $1 \%$ significance level confirming hypothesis $\mathrm{H} 2$ and $\mathrm{H} 3$. Furthermore, profitability was negatively related to short-term debt and total debt at a significance level of $1 \%$ and $5 \%$ respectively which is in line with the proposed hypotheses. Hence, failed to reject $\mathrm{H} 16$ and H18. In addition, the findings of the present study suggested that liquidity was significant and negatively related to all types of leverages thus confirming hypotheses $\mathrm{H} 7, \mathrm{H} 8$ and $\mathrm{H} 9$.

Meanwhile, the result also indicated that tangibility was positively related to all types of leverage although contrary to proposed hypothesis H13. Conversely, contrary to the proposed hypotheses H4 and H6, the business risk was positively related to short-term debt and total debt. Hence hypotheses H4 and H6 were rejected. Besides that, the results of the present study also suggested that the tangibility had the most impact on all types of leverages, followed by liquidity while growth had the least impact on all types of leverages.

Table 4.3: Pooled OLS Analysis based on Overall Samples Independent Variable FSIZE PROF LQTY TANG GRTH NTDS BRISK S

\begin{tabular}{|c|c|c|c|c|c|c|c|c|c|}
\hline \multirow{2}{*}{\multicolumn{2}{|c|}{$\stackrel{P^{P}}{\text { value }}$}} & \multirow{2}{*}{$\begin{array}{l}0.000 \\
6\end{array}$} & \multirow{3}{*}{$\begin{array}{l}* \star * \\
0.000 \\
4 \\
-0.06 \\
4\end{array}$} & \multirow{3}{*}{$\begin{array}{l}* * * \\
0.000 \\
2 \\
-0.01 \\
4\end{array}$} & * & \multirow{3}{*}{$\begin{array}{l}0.388 \\
-0.00 \\
3\end{array}$} & \multirow{3}{*}{$\begin{array}{l}0.385 \\
-0.42 \\
4\end{array}$} & \multicolumn{2}{|l|}{$\star \star \star *$} \\
\hline & & & & & $\begin{array}{l}0.065 \\
6\end{array}$ & & & $\begin{array}{l}<0.000 \\
1\end{array}$ & $\begin{array}{l}108 \\
0\end{array}$ \\
\hline \multirow{7}{*}{ 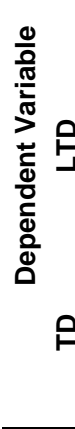 } & Coeff & 0.026 & & & 0.086 & & & 0.015 & \\
\hline & & * & & ** & $* * *$ & & & & \\
\hline & 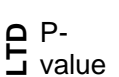 & $\begin{array}{l}0.056 \\
3\end{array}$ & 0.569 & $\begin{array}{l}0.013 \\
7\end{array}$ & $\begin{array}{l}0.007 \\
6\end{array}$ & 0.238 & 0.867 & 0.797 & 108 \\
\hline & Coeff & 0.011 & $\begin{array}{l}-0.00 \\
7\end{array}$ & $\begin{array}{l}-0.00 \\
3\end{array}$ & 0.099 & 0.002 & 0.096 & $\begin{array}{l}-0.000 \\
3\end{array}$ & \\
\hline & & $\star * *$ & ** & 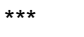 & 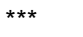 & & & $\star * *$ & \\
\hline & $\stackrel{P-}{P}$ value & $\begin{array}{l}0.000 \\
5\end{array}$ & $\begin{array}{l}0.010 \\
4\end{array}$ & $\begin{array}{l}0.000 \\
4\end{array}$ & $\begin{array}{l}0.006 \\
9\end{array}$ & 0.831 & 0.666 & $\begin{array}{l}<0.000 \\
1\end{array}$ & 108 \\
\hline & Coeff & 0.037 & $\begin{array}{l}-0.07 \\
1\end{array}$ & $\begin{array}{l}-0.01 \\
8^{-0.01}\end{array}$ & 0.185 & $\begin{array}{l}-0.00 \\
1\end{array}$ & $\begin{array}{l}-0.32 \\
8\end{array}$ & \multicolumn{2}{|l|}{0.014} \\
\hline
\end{tabular}

The table presents estimates of equation (3.4) using data from data stream from 2006-2015. This sample includes 108 firms within consumer product sector. The dependent variable are book leverage ratios (shot-term debt to total asset (STD), long-term debt to total asset (LTD), and total debt to total asset (TD)). The independent variables are firm size (FSIZE), profitability (EBIT), liquidity (LQTY), tangibility (TANG), growth (GRTH), non-tax debt shield (NDTS) and business risk (BRISK). *, ** and *** denote significance at $10 \%, 5 \%$ and $1 \%$ respectively.

\section{Fixed Effect Analysis Based on Overall Sample}


Table 4.4 shows the result of the fixed effect analysis between leverage and independent variables. From the overall sample, we can see only a slight difference from the OLS result. Firm size remained positively related to short-term debt and total debt at $1 \%$ significance level, while it became insignificant to long-term debt. Liquidity remained significant and negatively related to all types of leverages at $1 \%$ significance level with short-term debt and total debt, while being at 5\% significance level with long-term debt. Other than that, profitability is also still significant and negatively related to shortterm debt and total debt at $1 \%$ significance level.

In addition, business risk is significant and positively related to short-term debt and total debt at $1 \%$ significance level. Conversely, tangibility remained significant and positively related to long-term debt and total debt. Although tangibility became insignificant to short-term debt.

Table 4.4: Fixed Effect Analysis based on Overall Samples

\begin{tabular}{|c|c|c|c|c|c|c|c|c|c|}
\hline & \multicolumn{8}{|c|}{ Independent Variable } \\
\hline & & $\begin{array}{c}\text { FSIZ } \\
\mathrm{E}\end{array}$ & PROF & LQTY & $\begin{array}{c}\text { TAN } \\
\mathbf{G}\end{array}$ & $\begin{array}{c}\text { GRT } \\
\text { H }\end{array}$ & NTDS & BRISK & $\begin{array}{c}\text { OB } \\
\mathrm{S}\end{array}$ \\
\hline \multirow{8}{*}{ 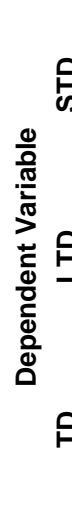 } & & $\star \star \star *$ & 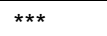 & $\star \star \star *$ & & & & 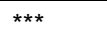 & \multirow{3}{*}{$\begin{array}{l}108 \\
0\end{array}$} \\
\hline & value & $\begin{array}{l}0.000 \\
3\end{array}$ & $\begin{array}{l}<0.000 \\
1\end{array}$ & $\begin{array}{l}<0.000 \\
1\end{array}$ & 0.101 & 0.377 & 0.603 & $\begin{array}{l}<0.000 \\
1\end{array}$ & \\
\hline & Coeff & 0.023 & -0.065 & -0.013 & 0.084 & $\begin{array}{l}-0.00 \\
3\end{array}$ & $\begin{array}{l}-0.27 \\
9\end{array}$ & 0.014 & \\
\hline & $\begin{array}{l}\mathrm{P} \text { - } \\
\text { value }\end{array}$ & 0.142 & 0.559 & $\begin{array}{l}\text { ** } \\
0.0409\end{array}$ & $\begin{array}{l}* * \\
0.014 \\
6\end{array}$ & 0.631 & 0.701 & 0.845 & \multirow{2}{*}{$\begin{array}{l}108 \\
0\end{array}$} \\
\hline & Coeff & 0.009 & -0.007 & -0.003 & 0.094 & 0.001 & 0.224 & -0.000 & \\
\hline & $P_{-}$ & 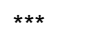 & & & $\star *$ & & & $* * *$ & \multirow{3}{*}{$\begin{array}{l}108 \\
0\end{array}$} \\
\hline & value & $\begin{array}{l}0.000 \\
5\end{array}$ & 0.0057 & 0.0005 & $\begin{array}{l}0.020 \\
1\end{array}$ & 0.641 & 0.946 & $\begin{array}{l}<0.000 \\
1\end{array}$ & \\
\hline & Coeff & 0.032 & -0.073 & -0.017 & 0.177 & $\begin{array}{l}-0.00 \\
2\end{array}$ & $\begin{array}{l}-0.05 \\
5\end{array}$ & 0.014 & \\
\hline
\end{tabular}

The table presents estimates of equation (3.5) using data from data stream from 2006-2015. This sample includes 108 firms within consumer product sector. The dependent variable are book leverage ratios (shot-term debt to total asset (STD), long-term debt to total asset (LTD), and total debt to total asset (TD)). The independent variables are firm size (FSIZE), profitability (EBIT), liquidity (LQTY), tangibility (TANG), growth (GRTH), non-tax debt shield (NDTS) and business risk (BRISK). *,** and *** denote significance at $10 \%, 5 \%$ and $1 \%$ respectively.

\section{Pooled OLS Analysis across Different Firm Sizes}

Table 4.5 shows the result of the relationship between the capital structure determinants and the debt ratios across different firm sizes, i.e. Large firms, medium firms and small firms. The independent variable profitability was removed from large firms and medium firms due to multicollinearity problem. The results highlighted the fact that firm size was positively related to all debt ratios across different firm sizes. Although it was only significant to long-term debt at $10 \%$ level in large firms, while firm size was significant to short-term debt and total debt at $10 \%$ level and 5\% level respectively in small firms.

Other than that, liquidity was negatively related and significant to all debt ratios except for long-term debt in large firms and medium firms. Moreover, liquidity was significant at $1 \%$ significance level to long-term debt in small firms. Meanwhile tangibility was only significant at $5 \%$ level and positively related to total debt in medium firms. Besides that, it was indicated that growth was negatively related to short-term debt in medium firms and total debt in small firms at $10 \%$ significance level and $1 \%$ significance level respectively.

Conversely, non-tax debt shield was only significant and negatively related to long-term debt in large firms at $10 \%$ significance level. Furthermore, business risk was significant at 5\% significance level and positively related to short-term debt and total debt in large firms, while positively related to long-term debt in medium firms. Based on the results, it shows that the relationship between capital structure determinants and leverage differ across different firm sizes which was in line with hypotheses $\mathrm{H} 22$. On the other hand, the coefficient of the non-tax debt shield confirms that it had the biggest impact on all debt ratios across all firm sizes.

Table 4.5: Pooled OLS Analysis Across Different Firm Sizes Independent Variable

\begin{tabular}{|c|c|c|c|c|c|c|c|c|c|}
\hline & & FSIZE & PROF & LQTY & TANG & GRTH & NTDS & $\begin{array}{c}\text { BRIS } \\
\mathrm{K}\end{array}$ & $\begin{array}{c}\text { OB } \\
\mathrm{S}\end{array}$ \\
\hline \multirow{4}{*}{ ص } & $\begin{array}{c}P- \\
\text { value }\end{array}$ & 0.318 & NA & $\begin{array}{c}{ }^{* *} \\
0.0388\end{array}$ & 0.225 & 0.850 & 0.306 & $\begin{array}{c}{ }^{* *} \\
0.033\end{array}$ & \multirow{2}{*}{340} \\
\hline & Coeff & 0.032 & NA & -0.007 & 0.238 & 0.001 & $\begin{array}{c}-2.59 \\
8\end{array}$ & 0.022 & \\
\hline & $\begin{array}{c}P- \\
\text { value }\end{array}$ & $\begin{array}{c}{ }^{*} \\
0.080 \\
8\end{array}$ & NA & 0.157 & 0.146 & 0.312 & $\begin{array}{c}0.090 \\
3\end{array}$ & 0.395 & \multirow[t]{2}{*}{340} \\
\hline & Coeff & 0.014 & NA & -0.001 & 0.109 & 0.003 & $\begin{array}{c}-0.48 \\
8\end{array}$ & 0.000 & \\
\hline \multirow[t]{2}{*}{ s } & $\begin{array}{c}\mathrm{P}- \\
\text { value }\end{array}$ & 0.253 & NA & $\stackrel{*}{*}$ & 0.201 & 0.569 & 0.251 & $\begin{array}{c}{ }^{* *} \\
0.041 \\
1\end{array}$ & \multirow[t]{2}{*}{340} \\
\hline & Coeff & 0.046 & NA & -0.009 & 0.347 & 0.004 & $\begin{array}{c}-3.08 \\
7\end{array}$ & 0.023 & \\
\hline \multirow{4}{*}{ 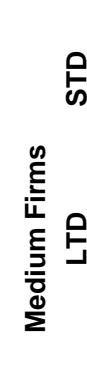 } & $\begin{array}{c}P- \\
\text { value }\end{array}$ & 0.243 & NA & $\begin{array}{c}{ }^{* *} \\
0.0256\end{array}$ & 0.470 & $\begin{array}{c}0.050 \\
2\end{array}$ & 0.206 & 0.143 & \\
\hline & Coeff & 0.043 & NA & -0.018 & 0.053 & $\begin{array}{c}-0.02 \\
0\end{array}$ & $\begin{array}{c}-0.57 \\
5\end{array}$ & 0.007 & 450 \\
\hline & $\begin{array}{c}\mathrm{P}- \\
\text { value }\end{array}$ & 0.172 & NA & 0.139 & 0.287 & 0.311 & 0.154 & $\begin{array}{c}{ }^{* *} \\
0.044 \\
6\end{array}$ & \multirow{2}{*}{450} \\
\hline & Coeff & 0.016 & NA & -0.005 & 0.090 & $\begin{array}{c}-0.00 \\
6\end{array}$ & $\begin{array}{c}-0.80 \\
1\end{array}$ & 0.003 & \\
\hline \multirow[t]{2}{*}{$\mathrm{s}$} & $\begin{array}{c}P- \\
\text { value }\end{array}$ & 0.224 & NA & $\stackrel{*}{*} 0.0512$ & $\begin{array}{c}{ }^{*} \\
0.021 \\
5\end{array}$ & 0.117 & 0.176 & 0.112 & \multirow[t]{2}{*}{450} \\
\hline & Coeff & 0.060 & NA & -0.023 & 0.143 & $\begin{array}{c}-0.02 \\
7\end{array}$ & $\begin{array}{c}-1.37 \\
7\end{array}$ & 0.011 & \\
\hline \multirow{2}{*}{ 号 } & $\begin{array}{c}P- \\
\text { value }\end{array}$ & $\begin{array}{c}{ }^{*} \\
0.073 \\
7\end{array}$ & 0.450 & $\begin{array}{c}* \\
0.082\end{array}$ & 0.169 & 0.235 & 0.211 & 0.583 & \multirow[t]{2}{*}{290} \\
\hline & Coeff & 0.061 & $\begin{array}{c}-0.18 \\
9\end{array}$ & -0.043 & $\begin{array}{c}-0.13 \\
0\end{array}$ & $\begin{array}{c}-0.05 \\
0\end{array}$ & 1.063 & 0.353 & \\
\hline \multirow{4}{*}{ 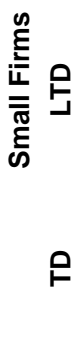 } & $\begin{array}{c}\text { P- } \\
\text { value }\end{array}$ & 0.264 & 0.922 & $\begin{array}{c}* 0.000 \\
1\end{array}$ & 0.776 & 0.840 & 0.259 & 0.433 & \multirow{4}{*}{290} \\
\hline & Coeff & 0.005 & 0.007 & -0.009 & 0.022 & 0.005 & 2.238 & $\begin{array}{c}-0.12 \\
3\end{array}$ & \\
\hline & $\begin{array}{c}\mathrm{P}- \\
\text { value }\end{array}$ & $\begin{array}{c}{ }^{* *} \\
0.045 \\
6\end{array}$ & 0.563 & $\begin{array}{c}* \\
0.0669\end{array}$ & 0.456 & $\begin{array}{c}{ }^{* * *} \\
0.006 \\
7\end{array}$ & 0.114 & 0.752 & \\
\hline & Coeff & 0.067 & $\begin{array}{c}-0.18 \\
1\end{array}$ & -0.053 & $\begin{array}{c}-0.10 \\
8\end{array}$ & $\begin{array}{c}-0.04 \\
5\end{array}$ & 3.301 & 0.230 & \\
\hline
\end{tabular}

The table presents estimates of equation (3.4) using data from data stream from 2006 to 2015. This sample includes 108 firms within consumer product sector. The sample size is divided into three size, i.e., Large firms, Medium firms and Small firms. The dependent variable are book leverage ratios (shot-term debt to total asset (STD), long-term debt to total asset (LTD), and total debt to total asset (TD)). The independent variables are firm size (FSIZE), profitability (EBIT), liquidity (LQTY), tangibility (TANG), growth (GRTH), non-tax debt shield (NDTS) and business risk (BRISK). *,** and *** denote significance at $10 \%, 5 \%$ and $1 \%$ respectively.

\section{Fixed Effect Analysis Across Different Firm Sizes}


Table 4.6 illustrates the result from the fixed effect analysis across different firm sizes. The result from the analysis shows that firm size has become a significant determinant of leverage across the different firm sizes. Firm size had a significance level of $1 \%$ towards shortterm debt in small firms, while it had significance level $1 \%$ to longterm debt in large and medium firms, as well as total debt in medium firms. The result also indicated that firm size had positive relationship with all types of leverages across different firm sizes.

As the cross-sectional effect was fixed, the result shows that liquidity had become a very significant determinant of leverage across different firm sizes at $1 \%$ significance level. The result highlighted that liquidity had negative relationship with all debt ratios across different firm sizes. Except for short-term debt and long-term debt of medium firms as well as long-term debt and total debt of small firms, tangibility was indicated to be significant to debt ratios across different firm sizes at $1 \%$ significance level. Tangibility had positive relationship with debt ratios except for short-term debt and total debt of small firms.

Besides that, growth was found to have a negative relationship with short-term debt and total debt in medium firms and small firms at $1 \%$ significance level. Furthermore, business risk was indicated to have positive relationship with short-term debt and long-term debt in large firms at $1 \%$ significance level. Meanwhile, business risk also had positive relationship with debt ratios in medium firms at $1 \%$ significance level as well. Moreover, result show that non-tax debt shield was significant at $1 \%$ significance level in medium and small firms. Non-tax debt shield also show a negative relationship with debt ratios in medium firms, while related to debt ratios positively in small firms.

On the other hand, the results revealed that there is different relationship between capital structure determinants and leverage across different firm sizes which confirmed the hypotheses H22. In addition, non-tax debt shield had the most impact to all types of leverage across all firm sizes. This is consistent with the pooled OLS analysis.

Table 4.6: Fixed Effect Analysis Across Different Firm Sizes

\begin{tabular}{|c|c|c|c|c|c|c|c|c|c|}
\hline & \multicolumn{9}{|c|}{ Independent Variable } \\
\hline & & FSIZE & $\begin{array}{c}\text { PRO } \\
\text { F }\end{array}$ & LQTY & TANG & GRTH & NTDS & $\underset{\mathrm{K}}{\text { BRIS }}$ & $\begin{array}{c}\text { OB } \\
S\end{array}$ \\
\hline \multirow{4}{*}{ 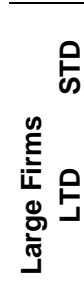 } & $\begin{array}{c}\mathrm{P}- \\
\text { value }\end{array}$ & $\begin{array}{c}* \\
0.0868\end{array}$ & NA & $\begin{array}{c}\star \star \star \star \\
<0.000 \\
1\end{array}$ & 0.0054 & 0.823 & 0.0626 & $\begin{array}{c}* \star * \\
<0.000 \\
1\end{array}$ & 340 \\
\hline & Coeff & $\underset{* * *}{0.033}$ & NA & -0.007 & 0.233 & 0.001 & -2.631 & 0.022 & \\
\hline & $\begin{array}{c}\mathrm{P}- \\
\text { value }\end{array}$ & $\begin{array}{c}<0.000 \\
1\end{array}$ & NA & $<0.000$ & $<0.000$ & 0.0617 & 0.0309 & 0.166 & 340 \\
\hline & Coeff & $\begin{array}{c}0.008 \\
\star *\end{array}$ & NA & $-\underset{* * \star}{0.001}$ & $\begin{array}{c}0.130 \\
* * *\end{array}$ & 0.003 & $\underset{* *}{-0.345}$ & $\underset{* * \star}{0.000}$ & \\
\hline \multirow{6}{*}{ 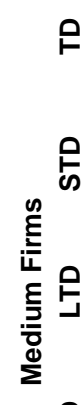 } & $\begin{array}{l}\text { P- } \\
\text { value }\end{array}$ & 0.0285 & NA & $\begin{array}{c}<0.000 \\
1\end{array}$ & 0.0006 & 0.396 & 0.0178 & $\begin{array}{c}<0.000 \\
1\end{array}$ & 340 \\
\hline & Coeff & 0.041 & NA & $-\underset{* * *}{0.009}$ & 0.363 & $\underset{* * *}{0.004}$ & -2.977 & $\underset{* * *}{0.022}$ & \\
\hline & $\begin{array}{l}P- \\
\text { value }\end{array}$ & 0.0135 & NA & $\begin{array}{c}<0.000 \\
1\end{array}$ & 0.209 & $\begin{array}{c}<0.000 \\
1\end{array}$ & 0.0009 & $\begin{array}{c}<0.000 \\
1\end{array}$ & 450 \\
\hline & Coeff & 0.045 & NA & $-\underset{* \star *}{0.018}$ & 0.063 & -0.021 & $-\underset{* * *}{0.603}$ & $\underset{* * *}{0.008}$ & \\
\hline & $\begin{array}{c}P- \\
\text { value }\end{array}$ & 0.0003 & NA & $\begin{array}{c}<0.000 \\
1\end{array}$ & 0.0315 & 0.0703 & $<\begin{array}{c}<.000 \\
1\end{array}$ & $\begin{array}{c}<0.000 \\
1\end{array}$ & 450 \\
\hline & Coeff & 0.017 & NA & $-\underset{* * *}{0.005}$ & $\underset{* \star *}{0.096}$ & -0.006 & -0.818 & $\underset{* * *}{0.004}$ & \\
\hline \multirow{5}{*}{ 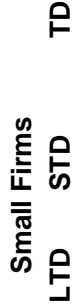 } & $\begin{array}{l}\mathrm{P}- \\
\text { value }\end{array}$ & 0.0067 & NA & $\begin{array}{c}<0.000 \\
1\end{array}$ & $\begin{array}{c}<0.000 \\
1\end{array}$ & $\begin{array}{c}<0.000 \\
1\end{array}$ & 0.0002 & $\begin{array}{c}<0.000 \\
1\end{array}$ & 450 \\
\hline & Coeff & $\underset{* \star *}{0.062}$ & NA & -0.023 & 0.159 & -0.028 & -1.422 & 0.012 & \\
\hline & $\begin{array}{l}\mathrm{P} \text { - } \\
\text { value }\end{array}$ & $\begin{array}{c}<0.000 \\
1\end{array}$ & 0.243 & $<0.000$ & 0.0017 & 0.0079 & 0.0437 & 0.452 & 290 \\
\hline & Coeff & 0.062 & $\begin{array}{c}-0.21 \\
0\end{array}$ & $\begin{array}{c}-0.043 \\
9\end{array}$ & -0.132 & -0.049 & 0.920 & 0.353 & \\
\hline & $\begin{array}{c}\mathrm{P}- \\
\text { value }\end{array}$ & 0.0876 & 0.426 & $\begin{array}{c}{ }^{* * *} \\
<0.000\end{array}$ & 0.612 & 0.820 & 0.0067 & 0.131 & 290 \\
\hline
\end{tabular}

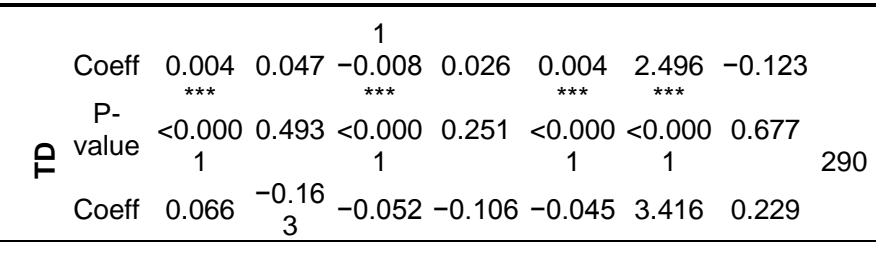

The table presents estimates of equation (3.5) using data from data stream from 2006 to 2015. This sample includes 108 firms within consumer product sector. The sample size is divided into three size, i.e., Large firms, Medium firms and Small firms. The dependent variable are book leverage ratios (shot-term debt to total asset (STD), long-term debt to total asset (LTD), and total debt to total asset (TD)). The independent variables are firm size (FSIZE), profitability (EBIT), liquidity (LQTY), tangibility (TANG), growth (GRTH), non-tax debt shield (NDTS) and business risk (BRISK). *, ** and *** denote significance at $10 \%, 5 \%$ and $1 \%$ respectively.

\section{DISCUSSION AND CONCLUSION}

Based on the results of the analysis, these findings highlight that firm size was found to be significant and had a positive relationship with leverage. This finding was similar to (Wellalage, N. H., 2013), who found that firm size and leverage is significantly positively related. This is also supported by several Malaysian studies who got the same result (Md-Yusuf et al., 2013); (Affandi et al., 2012). However, it is different from the findings of (Pacheco and Tavares, 2017), and (Proença et al., 2014) who both found the opposite result for Portuguese SMEs, where size resulted in a negative relationship. Besides that, profitability had a negative relationship with leverage. This is similar to several authors findings (Pacheco and Tavares, 2017); (Alzomaia, 2014); (Gómez et al., 2014); (Proença et al., 2014). (Wahab, S. N., \& Ramli, 2014) and (Affandi et al., 2012) also confirmed that in Malaysia, firms tend to reduce their debt capacity when they have high profit that follows the pecking order theory. Other than that, the relationship between liquidity and leverage was found to be significantly negative. This is dissimilar to (Al-Najjar, 2011), who found that when firms have high liquidity, they will increase their leverage. Meanwhile, (Proença et al., 2014) and (Abu Mouamer, 2011) found that liquidity is negatively related to shortterm debt while positively related to long-term debt. (Wahab, S. N., \& Ramli, 2014), (Haron, 2014), and (Haron and Ibrahim, 2012) have found similar result where liquidity has a negative relationship to long-term debt and total debt among Malaysian firms.

Conversely, tangibility significant and had a positive relationship with long-term debt and total debt. This finding is similar to (Proença et al., 2014), who found that there is a positive relationship between tangibility and long-term debt. Although it is dissimilar to several researchers who emphasized that tangibility and leverage is negatively related supporting the pecking order theory (Jahanzeb et al., 2015); (Alzomaia, 2014); (Wellalage, N. H., 2013); (Ahmed Sheikh and Wang, 2011); (Sbeiti, 2010). Business risk was positively related to short-term debt and total debt. Studies by (Alzomaia, 2014), (Wellalage, N. H., 2013), (Al-Najjar, 2011), and (Feidakis, A., \& Rovolis, 2007) was dissimilar where they found that there was a negative relationship between risk and leverage. Nevertheless, (Ramakrishnan, 2012), and (Pandey and Chotigeat, 2004) showed that there is a positive relationship between risk and short-term debt while risk is negatively related to long-term debt. Thus, it can be concluded that the relationship between capital structure determinants and leverage differs across different firm sizes.

\section{Recommendations}

After conducting this study, some recommendations for future research should be pointed out. They are: -

1. More study should be conducted in other sectors in Malaysia as well so that the result would be more accurate. 
2. Future studies on capital structure should include the factor of Zealand firms. J. Bus. Econ. Manag. 14, 852-866. different firm sizes.

3. Study period should be longer which may provide better understanding of the behavior of capital structure determinants across different firm sizes.

\section{REFERENCES}

Abu Mouamer, F.M., 2011. The determinants of capital structure of Palestinelisted companies. J. Risk Financ. 12, 226-241.

Affandi, S., Mahmood, W.M.W., Shukur, N.A., 2012. Capital Structure of Property Companies in Malaysia Based on Three Capital Structure Theories.

Ahmed Sheikh, N., Wang, Z., 2011. Determinants of capital structure: An empirical study of firms in manufacturing industry of Pakistan. Manag. Financ. 37, 117-133.

Al-Najjar, B., 2011. Empirical modelling of capital structure: Jordanian evidence. J. Emerg. Mark. Financ. 10, 1-19.

Alzomaia, T.S., 2014. Capital Structure Determinants of Publicly Listed Companies in Saudi Arabia. Int. J. Bus. Financ. Res. 8, 53-67.

Cortez, M. A., \& Susanto, S., 2012. The determinants of corporate capital structure: evidence from Japanese manufacturing companies. J. Int. Bus. Res. 11, 121-134.

Feidakis, A., \& Rovolis, A., 2007. Capital structure choice in European Union: evidence from the construction industry. Appl. Financ. Econ. 17, 9891002.

Gómez, G., Mena Rivas, A., \& Lizarzaburu Bolaños, E.R., 2014. The determinants of capital structure in Peru. Acad. Rev. Latinoam. Adm. 27, 341-354.

Haron, R., 2014. Key factors influencing target capital structure of property firms in Malaysia. Asian Soc. Sci. 10, 62.

Haron, R., Ibrahim, K., 2012. Target capital structure and speed of adjustment: Panel data evidence on Malaysia Shariah compliant securities. Int. J. Econ. Manag. Account. 20, 87.

Jahanzeb, A., Bajuri, N.H., Ghori, A., 2015. Market power versus capital structure determinants: Do they impact leverage? Cogent Econ. Financ. 3, 1017948 .

Khrawish, H.A., Khraiwesh, A.H.A., 2010. The determinants of the capital structure: evidence from Jordanian industrial companies. J. King Abdulaziz Univ. Econ. Adm. 105, 1-48.

Md-Yusuf, M., Yunus, F.M., Supaat, N.Z.L.M., 2013. Determinants of capital structure in Malaysia electrical and electronic sector. Int. J. Soc. Manag. Econ. Bus. Eng. 7, 676-681.

Modigliani, F., Miller, M.H., 1958. The cost of capital, corporation finance and the theory of investment. Am. Econ. Rev. 48, 261-297.

Myers, S.C., Majluf, N.S., 1984. Corporate financing and investment decisions when firms have information that investors do not have. J. financ. econ. 13, 187-221.

Pacheco, L., Tavares, F., 2017. Capital structure determinants of hospitality sector SMEs. Tour. Econ. 23, 113-132.

Pandey, I.M., Chotigeat, T., 2004. Theories of capital structure: Evidence from an emerging market. Stud. Econ. Financ. 22, 1-19.

Proença, P., Laureano, R.M.S., Laureano, L.M.S., 2014. Determinants of capital structure and the 2008 financial crisis: evidence from Portuguese SMEs. Procedia-Social Behav. Sci. 150, 182-191.

Ramakrishnan, S., 2012. Sectoral analysis on capital structure determinants among the Malaysia listed firms. Deakin University.

Saarani, A.N., Shahadan, F., 2013. The determinant of capital structure of SMEs in Malaysia: evidence from enterprise 50 (E50) SMEs. Asian Soc. Sci. 9, 64.

Sbeiti, W., 2010. The determinants of capital structure: Evidence from the GCC countries. Int. Res. J. Financ. Econ. 47, 56-82.

Shah, S.Z.A., Jam-e-Kausar, 2012. Determinants of capital structure of leasing companies in Pakistan. Appl. Financ. Econ. 22, 1841-1853.

Tornyeva, K., 2013. Determinants of capital structure of insurance companies in Ghana. Res. J. Financ. Account. 4, 52-60.

Viviani, J.-L., 2008. Capital structure determinants: an empirical study of French companies in the wine industry. Int. J. Wine Bus. Res. 20, 171194.

Wahab, S. N., \& Ramli, N.A., 2014. The Determinants of Capital Structure: An Empirical Investigation of Malaysian Listed Government Linked Companies. Int. J. Econ. Financ. Issues 4, 930-945.

Wahab, R.A., Amin, M.S.M., Yusop, A.K., 2012. Determinants of capital structure of Malaysian property developers. Middle East J. Sci. Res. $11,1013-1021$

Wellalage, N. H., \& L.S., 2013. Capital structure and its determinants in New 